Review

\title{
Elucidating Biological Roles of Novel Murine Genes in Hearing Impairment in Africa
}

\author{
Oluwafemi Gabriel Oluwole, ${ }^{1 *}$ Abdoulaye Yal ${ }^{1,2}$, Edmond Wonkam ${ }^{1}$, Noluthando Manyisa ${ }^{1}$, Jack \\ Morrice$^{1}$, Gaston K. Mazanda ${ }^{1}$ and Ambroise Wonkam ${ }^{1 *}$ \\ ${ }^{1}$ Division of Human Genetics, Department of Pathology, Faculty of Health Sciences, University of Cape Town, \\ Observatory, Cape Town, South Africa. \\ ${ }^{2}$ Department of Neurology, Point G Teaching Hospital, University of Sciences, Techniques and Technology, \\ Bamako, Mali. \\ *Correspondence to: ambroise.wonkam@uct.ac.za; oluwafemi.oluwole@uct.ac.za
}

\begin{abstract}
The prevalence of congenital hearing impairment (HI) is highest in Africa. Estimates evaluated genetic causes to account for $31 \%$ of $\mathrm{HI}$ cases in Africa, but the identification of associated causative genes mutations have been challenging. In this study, we reviewed the potential roles, in humans, of 38 novel genes identified in a murine study. We gathered information from various genomic annotation databases and performed functional enrichment analysis using online resources i.e. genemania and g.proflier. Results revealed that 27/38 genes are express mostly in the brain, suggesting additional cognitive roles. Indeed, HERC1- R3250X had been associated with intellectual disability in a Moroccan family. A homozygous 216-bp deletion in KLC2 was found in two siblings of Egyptian descent with spastic paraplegia. Up to 27/38 murine genes have link to at least a disease, and the commonest mode of inheritance is autosomal recessive $(n=8)$. Network analysis indicates that 20 other genes have intermediate and biological links to the novel genes, suggesting their possible roles in HI. This study will contribute to advance our knowledge in unravelling the biological roles of novel murine HI genes in humans and could enhance the understanding the genetic causes of $\mathrm{HI}$ in Africans.
\end{abstract}

Keywords: Hearing impairment; Novel Murine Genes; Gene enrichment; Africa

\section{Introduction}

Hearing impairment $(\mathrm{HI})$ remains the most disabling congenital diseases, with the highest rate for age-standardized disability life years which is $\sim 1.5-2 \mathrm{x}$ that of e.g. congenital heart disease $[1,2]$. Moreover, up to $90 \%$ of deaf children are born to hearing parents, which add additional emotional and parenting burden on parents of children affected by HI [3]. It has been estimated that by the year 2050 over 900 million people will have disabling hearing loss [4]. Non-preventable cases of HI are increasing drastically, particularly among the new-borns and older adults, whilst genetic causes account for $31 \%$ of HI (Figure 1). Genetic screening for pathogenic mutations in HI could enhance the knowledge of $\mathrm{HI}$ and shed more light on the complexity of this disorder. More than one hundred genes have been associated with HI pathology, though mutations in two genes, GJB2 and GJB6, account for $50 \%$ of patients with autosomal recessive $\mathrm{HI}$ in most populations of European and Asian ancestry [5]. Deletions that caused frameshifts and missense mutations in these genes, that severely disrupt the protein structures were commonly associated with hereditary HI [6, 7].

In Africa, the highest numbers of children with HI reside in Nigeria, Ghana, Cameroon, Sudan, Kenya, Tanzanian, Zimbabwe, Uganda and South Africa [8]. Of these cases syndromic and non-syndromic $\mathrm{HI}$ are common. In non-syndromic cases, autosomal recessive is the most common inheritance pattern [9]. Despite many identified genes, only GJB2 and GJB6 have been systematically studied in sub-Saharan Africans, for which prevalence of NSHI-causal variants is close to zero [10]. Therefore, little is known about the underlying role of causative genes in HI. Susceptible variants 
identified so far [11, 12], only explained a small proportion of individual variation at risk of HI. Extreme genetic variability in African populations provides unique opportunities to discover new genes variants. In this study, we reviewed the 38 newly identified murine HI genes [13] and explored the interest in investigations these genes in $\mathrm{HI}$ genetics in Africa.

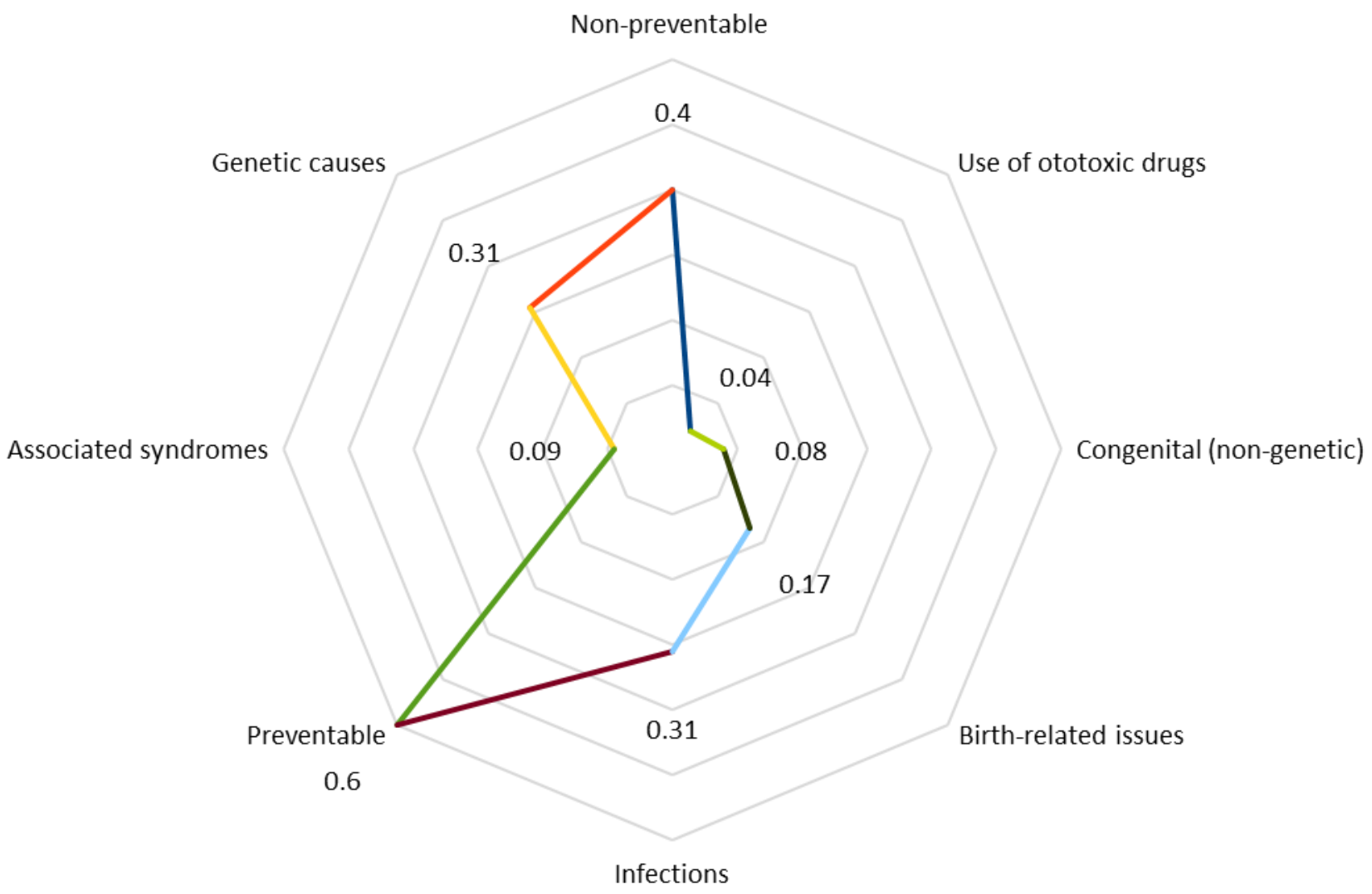

Figure 1. Estimated data on the causes of Hearing Impairment derived from the World Health Organization deafness and hearing loss fact sheet March 2019. Genetic causes account for $31 \%$ of the $40 \%$ Non-preventable cases linked to congenital hearing impairment. (Syndromic and non-syndromic hearing impairment are considered non-preventable).

\section{Methods}

A recent study by Ingham et al used a genetic approach to identify new molecules involved in HI by screening a large cohort of newly generated mouse mutants using a sensitive electrophysiological test and the auditory brainstem response [13]. From the unbiased sample of 1,211 genes tested, they found 38 genes to be involved in HI.

In this study we gathered information from the various genomic annotation databases, such as the Online Mendelian Inheritance in Man (OMIM), HUGO Gene Nomenclature Committee (HGNC), Clinical significance for the variant (ClinVar), Exome Aggregation Consortium (ExAC), GeneCards, g.profilier, Genemania, Genome-wide association study (GWAS) catalog, Genotype-Tissue Expression (GTEx) and SAGE (Serial Analysis of Gene Expression) and Gene Ontology (GO); We estimated numbers of synonymous, missense, loss of function, and copy number variants reported on each genes in the ExAC database. Furthermore, we used OMIM, GO and GeneCards to elucidate candidate genes previously associated with this disorder. We used g-profilier to determine the biological significance, while we used genemania for the gene enrichment and protein-protein interaction (PPI) network analyses. GeneCards, GTEx and SAGE were used for determining the 
expression of each gene in an organ. From the panoramas of events, we achieved a concordance used for the inference.

\section{Results}

We identified 38 genes that showed biological significance (Figure 2). Four genes (d6wsu163e, zfp719, grp152 and minar2) are Mus musculus genes. The information obtained from g.profilier suggested that the novel genes are constituted mostly in the extracellular, plasma membrane, and the nucleus (Figure 2). Similarly, the genes have nucleic acid binding activities as well as signal transduction activity, likewise, by far these genes are involved in developmental processes, transcription factors and cell biogenesis (Figure 2). The g.profilier maps genes to known functional information sources and detects statistically enriched GO annotations.

Table 1 shows that 27 genes are expressed mostly in the brain. However, further work will be required to investigate the roles of these genes in the auditory pathways and neuronal functions variants identified in these 27 genes have been previously associated with certain diseases, of which, the most common mode of inheritance is autosomal recessive $(n=8)$. Studies that used GWAS method significantly associated some variants in 17 genes with certain diseases (Table 1).

The network analysis also shows that $77.5 \%$ of genes are co-expressed, $2.0 \%$ shares a protein domain, $7.0 \%$ shares a miRNA target and $5.2 \%$ shares a transcription factor target. Interestingly, another 20 human genes (BA1AP2, ARHGAP1, PEX16, BHLHE41, PEX26, KIF5B, ACSL3, NTSR2, OSBPL3, ACSL5, KLC4, MAKK2, KIF1B, ZFP36L2, FAM53C, KLC3, PAK4, SLC11A2, DDX46, FGGY), were directly connected with the novel HI genes (Figure 3), through the intermediate nodes, suggesting that these 20 genes also are potential genes of interest in HI genetics.

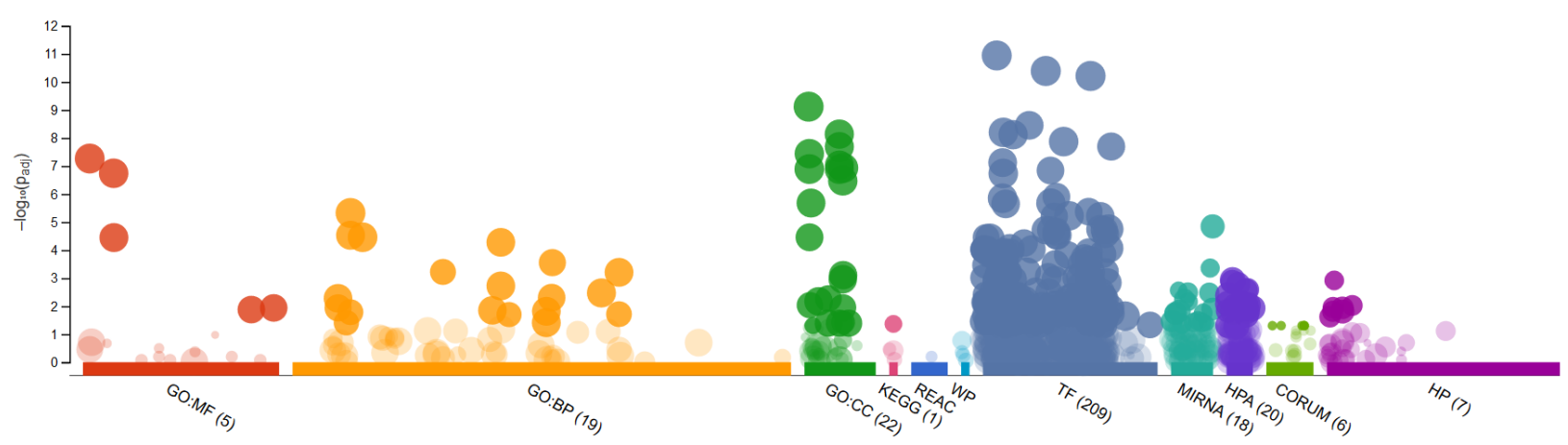

Figure 2. Functional enrichment analyses predicting the distributions of the 34 novel human genes involved in different biological and cellular pathways, and their correlation with disease ontology. This figure further shows a strong transcriptional regulation between the novel genes and regulatory motif matches from TRANSFAC (TF). Data was retrieved at (https://biit.cs.ut.ee/gprofiler/gost) on the 20 June 2019. 
Table 1. Summary of the 38 novel murine genes associated with Hearing Impairment and relation to human diseases.

\begin{tabular}{|c|c|c|c|c|c|c|c|c|}
\hline Gene & Chr & $\begin{array}{c}\text { Mostly } \\
\text { expressed in }\end{array}$ & MOI & $\begin{array}{l}\text { Previously associated } \\
\text { with (in Humans) }\end{array}$ & $\begin{array}{l}\text { Types } \\
\text { of study }\end{array}$ & $\begin{array}{l}\text { Number of } \\
\text { Significant } \\
\text { SNPs/Mutation }\end{array}$ & $\begin{array}{l}\text { Number } \\
\text { of } \\
\text { variants } \\
\text { (ExAC) }\end{array}$ & $\begin{array}{c}\text { Number of } \\
\text { variants with } \\
\text { clinical } \\
\text { relevance } \\
\text { (ClinVar) }\end{array}$ \\
\hline $\operatorname{acs} / 4$ & $\mathrm{x}$ & Brain & X-linked & Mental retardation & $\begin{array}{l}\text { Co-segregation } \\
\text { and human cell } \\
\text { lines screening }\end{array}$ & $\begin{array}{l}\text { ARG529SER } \\
\text { PRO375LEU }\end{array}$ & 150 & 149 \\
\hline agap1 & 2 & $\begin{array}{c}\text { Brain and } \\
\text { Kidney }\end{array}$ & N/A & $\begin{array}{l}\text { Intellectual and } \\
\text { developmental } \\
\text { disabilities }\end{array}$ & GWAS & 10 & 528 & 46 \\
\hline bai1 & 8 & Brain & $\mathrm{N} / \mathrm{A}$ & Long QT syndrome & GWAS & 4 & 554 & 34 \\
\hline ^bhlhe40 & 3 & Cartilage & N/A & $\begin{array}{c}\text { Cancer and dysmorphic } \\
\text { brain development }\end{array}$ & GWAS & 2 & 198 & 55 \\
\hline${ }^{\wedge} b r d 2$ & 6 & Brain & N/A & $\begin{array}{l}\text { Rheumatoid arthritis } \\
\text { and type } 1 \text { diabetes }\end{array}$ & GWAS & 7 & 459 & 7 \\
\hline ^camsap3 & 19 & Brain & N/A & $\begin{array}{l}\text { Peripheral arterial } \\
\text { disease }\end{array}$ & GWAS & 1 & 503 & 6 \\
\hline cdk14 & 7 & $\begin{array}{l}\text { Brain/ } \\
\text { Retina }\end{array}$ & $\mathrm{N} / \mathrm{A}$ & $\begin{array}{l}\text { Systolic high blood } \\
\text { pressure }\end{array}$ & GWAS & 1 & 194 & 10 \\
\hline csnk1g3 & 5 & $\begin{array}{l}\text { Bone } \\
\text { marrow }\end{array}$ & N/A & $\begin{array}{c}\text { Lipid trait disorder and } \\
\text { heel bone mineral } \\
\text { density }\end{array}$ & GWAS & 6 & 150 & 18 \\
\hline ‘cxcr2 & 2 & Whole blood & N/A & Inflammatory diseases & GWAS & 10 & 193 & 14 \\
\hline $\begin{array}{c}* d 6 w s u 1 \\
63 e\end{array}$ & - & 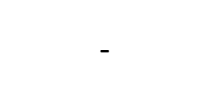 & - & - & - & - & - & - \\
\hline ^duoxa2 & 15 & $\begin{array}{l}\text { Thyroid } \\
\text { gland }\end{array}$ & $A R$ & $\begin{array}{c}\text { Thyroid } \\
\text { dyshormonogenesis } \\
\text { Plasma omega-3 }\end{array}$ & Family screening & TYR246TER & 232 & 14 \\
\hline${ }^{\wedge} f a d s 3$ & 11 & Brain & N/A & $\begin{array}{c}\text { polyunsaturated fatty } \\
\text { acid level }\end{array}$ & GWAS & 3 & 169 & 4 \\
\hline${ }^{\wedge}$ fam107b & 10 & Whole blood & N/A & Barakat syndrome & GWAS & 1 & 182 & 14 \\
\hline$f b \times 033$ & 14 & $\begin{array}{l}\text { Brain/ } \\
\text { Retina }\end{array}$ & $\mathrm{N} / \mathrm{A}$ & $\begin{array}{l}\text { Attention deficit } \\
\text { disorder }\end{array}$ & GWAS & 1 & 223 & 20 \\
\hline
\end{tabular}




\begin{tabular}{|c|c|c|c|c|c|c|c|c|}
\hline Gene & Chr & $\begin{array}{c}\text { Mostly } \\
\text { expressed in }\end{array}$ & MOI & $\begin{array}{l}\text { Previously associated } \\
\text { with (in Humans) }\end{array}$ & $\begin{array}{l}\text { Types } \\
\text { of study }\end{array}$ & $\begin{array}{c}\text { Number of } \\
\text { Significant } \\
\text { SNPs/Mutation }\end{array}$ & $\begin{array}{l}\text { Number } \\
\text { of } \\
\text { variants } \\
\text { (ExAC) }\end{array}$ & $\begin{array}{l}\text { Number of } \\
\text { variants with } \\
\text { clinical } \\
\text { relevance } \\
\text { (ClinVar) }\end{array}$ \\
\hline 'gas $2 / 2$ & 17 & $\begin{array}{l}\text { Skeletal } \\
\text { muscle }\end{array}$ & $A R$ & Ciliary dyskinesia & $\begin{array}{c}\text { Family, } \\
\text { case/control }\end{array}$ & Val296Glyfs & 552 & 6 \\
\hline grp152 & - & - & - & - & - & - & - & - \\
\hline herc1 & 15 & $\begin{array}{l}\text { Brain, } \\
\text { whole blood }\end{array}$ & $A R$ & $\begin{array}{l}\text { Macrocephaly, } \\
\text { dysmorphic facies, and } \\
\text { psychomotor } \\
\text { retardation }\end{array}$ & $\begin{array}{l}\text { Co-segregation } \\
\text { Analyses }\end{array}$ & $\begin{array}{l}\text { GLY4520GLU } \\
\text { ARG3250TER }\end{array}$ & 1760 & 11 \\
\hline${ }^{\wedge} \mathrm{klc2}$ & 11 & $\begin{array}{l}\text { Brain, } \\
\text { Retina }\end{array}$ & $A R$ & $\begin{array}{l}\text { Spastic paraplegia, optic } \\
\text { atrophy, and } \\
\text { neuropathy }\end{array}$ & $\begin{array}{l}\text { Family, } \\
\text { case/control }\end{array}$ & 216bp DEL & 300 & 8 \\
\hline$k \mid h / 18$ & 3 & $\begin{array}{l}\text { Brain, } \\
\text { Retina }\end{array}$ & $\mathrm{N} / \mathrm{A}$ & $\mathrm{N} / \mathrm{A}$ & $\mathrm{N} / \mathrm{A}$ & N/A & 261 & 6 \\
\hline Irig1 & 3 & $\begin{array}{l}\text { Brain, } \\
\text { Heart }\end{array}$ & $\mathrm{N} / \mathrm{A}$ & Heart disease & GWAS & 7 & 751 & 8 \\
\hline mcph1 & 8 & $\begin{array}{l}\text { Brain, } \\
\text { Skeletal } \\
\text { muscle }\end{array}$ & $A R$ & Microcephaly & $\begin{array}{l}\text { Family, } \\
\text { case/control }\end{array}$ & 6 & 716 & 93 \\
\hline${ }^{*}$ minar2 & - & - & - & - & - & - & - & - \\
\hline 'mir122 & 18 & Liver & N/A & $\begin{array}{l}\text { Serum gamma-glutamyl } \\
\text { transferase }\end{array}$ & GWAS & 1 & 22 & 55 \\
\hline$m k r n 2$ & 3 & $\begin{array}{c}\text { Brain, } \\
\text { Whole blood }\end{array}$ & $\mathrm{N} / \mathrm{A}$ & Blood disease & GWAS & 2 & 222 & 20 \\
\hline nocm & 7 & Brain & N/A & N/A & N/A & N/A & 55 & 32 \\
\hline paxe & 14 & $\begin{array}{l}\text { Brain, } \\
\text { oesophagus }\end{array}$ & $A D$ & Tooth agenesis & $\begin{array}{l}\text { Co-segregation } \\
\text { Analyses }\end{array}$ & 15 & 165 & 46 \\
\hline pex3 & 6 & $\begin{array}{l}\text { Brain, } \\
\text { Heart }\end{array}$ & $A R$ & $\begin{array}{l}\text { Peroxisome biogenesis } \\
\text { disorder }\end{array}$ & $\begin{array}{l}\text { Family, } \\
\text { case/control }\end{array}$ & 4 & 141 & 18 \\
\hline phf 20 & 20 & $\begin{array}{l}\text { Brain, } \\
\text { Kidney }\end{array}$ & N/A & $\begin{array}{l}\text { Schizophrenia, Skin } \\
\text { carcinoma }\end{array}$ & GWAS & 3 & 396 & 10 \\
\hline ^selk & 3 & Spleen & $\mathrm{N} / \mathrm{A}$ & N/A & N/A & N/A & 44 & 6 \\
\hline setd5 & 3 & Brain & $A D$ & Mental retardation & Case/control & 7 & 636 & 72 \\
\hline spns2 & 17 & Brain & $A R$ & Deafness & Family study & DEL, 955TCC & 368 & 21 \\
\hline
\end{tabular}




\begin{tabular}{|c|c|c|c|c|c|c|c|c|}
\hline Gene & Chr & $\begin{array}{c}\text { Mostly } \\
\text { expressed in }\end{array}$ & MOI & $\begin{array}{l}\text { Previously associated } \\
\text { with (in Humans) }\end{array}$ & $\begin{array}{l}\text { Types } \\
\text { of study }\end{array}$ & $\begin{array}{c}\text { Number of } \\
\text { Significant } \\
\text { SNPs/Mutation }\end{array}$ & $\begin{array}{l}\text { Number } \\
\text { of } \\
\text { variants } \\
\text { (ExAC) }\end{array}$ & $\begin{array}{c}\text { Number of } \\
\text { variants with } \\
\text { clinical } \\
\text { relevance } \\
\text { (ClinVar) }\end{array}$ \\
\hline srsf7 & 2 & $\begin{array}{c}\text { Brain, } \\
\text { Whole blood }\end{array}$ & N/A & $\mathrm{N} / \mathrm{A}$ & $\mathrm{N} / \mathrm{A}$ & $\mathrm{N} / \mathrm{A}$ & 77 & 13 \\
\hline tram2 & 6 & $\begin{array}{l}\text { Brain, Skin } \\
\text { Lymph node }\end{array}$ & N/A & Childhood onset asthma & GWAS & 1 & 149 & 10 \\
\hline usp42 & 7 & $\begin{array}{l}\text { Brain, Skin } \\
\text { Lymph node }\end{array}$ & $\mathrm{N} / \mathrm{A}$ & $\mathrm{N} / \mathrm{A}$ & $\mathrm{N} / \mathrm{A}$ & $\mathrm{N} / \mathrm{A}$ & 762 & 31 \\
\hline wbp2 & 17 & Brain & AR & Deafness & Exons screening & $\begin{array}{l}\text { ALA160THR } \\
\text { ALA224VAL } \\
\text { MET163LEU }\end{array}$ & 150 & 15 \\
\hline Ywhae & 17 & $\begin{array}{c}\text { Brain, } \\
\text { Lymph node }\end{array}$ & N/A & $\begin{array}{l}\text { Schizophrenia, } \\
\text { Heart disease }\end{array}$ & GWAS & 3 & 105 & 69 \\
\hline zcchc14 & 16 & $\begin{array}{c}\text { Brain, } \\
\text { Lymph node }\end{array}$ & N/A & $\mathrm{N} / \mathrm{A}$ & N/A & $\mathrm{N} / \mathrm{A}$ & 589 & 35 \\
\hline${ }^{*} z f p 719$ & - & - & - & - & - & - & - & - \\
\hline
\end{tabular}

Not Available: N/A, Autosomal recessive: AR, Autosomal Dominant: AD, Genome-wide association study: GWAS. Chromosome: Chr, Mode of Inheritance: MOI. Asterisks $\left[{ }^{*}\right.$ ] represent genes specific to Mus musculus. Combining with a Circumflex [ ] represents genes that have shorter introns that are less than five introns; and with each of them have $<500$ nucleotides base pairs (https://www.ensembl.org). 


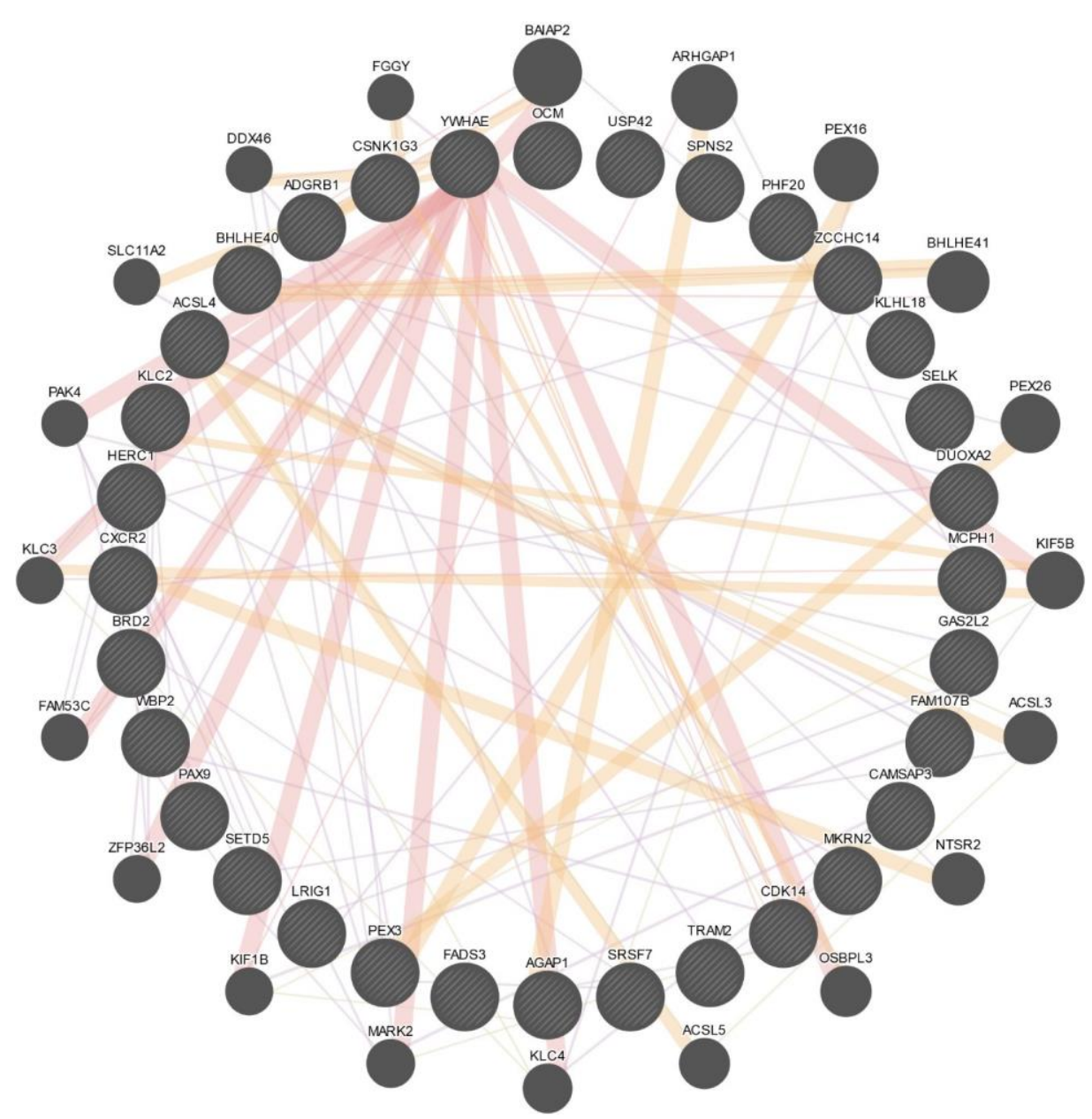

Figure 3. Network analysis predicting the interactions between the 38 novel human genes, and another 20 genes that formed an association with the novel genes through their intermediate nodes. Data was accessed at (https://genemania.org/) on the 15 August 2019.

\section{Discussion}

Different techniques and approaches can be used to identify pathogenic mutations or discover novel genes, Ingham et al screened a large cohort of newly generated mouse mutants using a sensitive electrophysiological test and the auditory brainstem response and identified 38 novel genes associated with HI [13]. It is noteworthy that limited information exists on these genes, therefore, necessitating further studies to establish their roles in HI in humans. Indeed, about two-thirds of $\sim 340$ mouse genes known to cause inner ear dysfunction, have not yet been linked to deafness in humans [14]. Moreover, Mendelian genetic hearing loss often reflects the loss of function of highly conserved Bottleneck genes, such as those that encode hair cell-specific structures like stereocilia. These 38 novel murine genes are highly conserved in mammals. Notably, Ingham et al however identified novel compound heterozygous mutations (Pro356CysfsTer35 and S319del) in a 2-year-old girl with severe sensorineural HI in one of the novel genes (SPNS2), confirming the role of one of the novel murine genes in childhood deafness [13].

While these novel murine genes have not been investigated systematically in the African populations, HERC1 gene has been screened for pathogenic mutation in a Moroccan family with intellectual disability, associated with an arg3250-to-ter (R3250X) substitution [15]. The mutation, which was found by whole-exome sequencing and confirmed by Sanger sequencing, segregated with the disorder in the family [15]. Two siblings of Egyptian descent with spastic paraplegia, optic 
atrophy, and neuropathy were identified with a homozygous 216-bp deletion in the noncoding upstream promoter region of the KLC2 gene [16]. It is necessary to study further the roles of these two genes in other African populations. Likewise, it is crucial to investigate further, the eight autosomal recessive genes in future studies, among humans and specifically the understudied African populations.

Of note, 27 genes show high expression in the brain. Brain coordinate the hearing system, with nerve impulses transmitted by the afferent auditory pathway supporting the neuronal electrical signals and synaptic transmission in the brain resulting in hearing [17-21]. But is possible these genes could be also associated to other neurodevelopmental conditions, this remains to be investigated.

Besides, some of these novels murine HI genes have shorter introns, which we identified on the Ensembl genome browser. It has been demonstrated that highly expressed genes tend to have shorter introns [22]. Indeed, the known causative HI genes (GJB2 and GJB6) have shorter intronic sequences. However, none of the 38 novel murine genes can be associated with GJB2 and GJB6, based on chromosomal mapping method for associated genes on a locus, because none of these novel genes is located on chromosome 13 .

Numerous variants were found in the equivalent of these novel murine genes in Humans and documented in ExAC database. But their significance in human pathologies remains to be investigated particularly in understudied African populations, with highest diversity. Particularly with the use of Next-generation sequencing (NGS) has been so effective and becoming relatively affordable for genetic screening because it is driving progress in genomics [23, 24].

To further understand the underlying mechanisms of these novel murine HI genes, the network interactions suggest complex interactions with other genes (Figure 3.) that could be relevant in HI. For example, Cadherin-related $23(\mathrm{CDH} 23)$ is an adhesive protein important for hearing and vision [25]. Mutation of $C D H 23$ is known to cause various degrees of $\mathrm{HI}$ including Usher Syndrome [26]. A study has shown that CAMSAP3 gene, one of the 38 novel HI genes, directly form binding with the $\mathrm{CDH} 23$ gene, a known causative $\mathrm{HI}$ gene, thereafter forming a microtubule network that modifies its function [25]. Therefore, the other 20 genes identified in networking with the 38 novel murine genes in our study should be investigated further when studying the genetics of $\mathrm{HI}$ pathology.

\section{Conclusion}

The results of the conducted analyses suggest that the novel murine genes are candidates' genes to be included in the list of genes to explore for HI pathology in Africa. Based on these observations we hypothesize that missense, loss-of-function, stop-gain, stop loss or copy number variation found in the novel genes, should be investigated further to establish their role in $\mathrm{HI}$ in humans. This study could contribute to enhance the understanding of the genetic causes of $\mathrm{HI}$ in Africans.

Acknowledgements: The study was funded by the NIH, USA, grant number U01-HG-009716 to AW, and the African Academy of Science/Wellcome Trust, grant, number H3A/18/001 to AW. The funders had no role in study design, data collection and analysis, decision to publish, or preparation of the manuscript.

Author contributions: OG. Oluwole carried out literature searches, performed the analyses, generated figures, tables and drafted the manuscript. A. Yal carried out literature searches, N. Manyisa and E. Wonkam contributed to the scope of the study, G. Mazanda and J. Morrice revised the manuscript. A. Wonkam is the project lead and critically appraised the manuscript.

Conflict of interest: The authors declare that the research was conducted in the absence of any commercial or financial relationships that could be taken as a potential conflict of interest.

\section{References}

1. Murray, C.J.L.; Barber, R.M.; Foreman, K.J.; Abbasoglu-Ozgoren, A.; Abd-Allah, F.; Abera, S.F.; Aboyans, V.; et al. Global, regional, and national disability-adjusted life years (DALYs) for 306 
diseases and injuries and healthy life expectancy (HALE) for 188 countries, 1990-2013: quantifying the epidemiological transition. Lancet. 2015, 386, 2145-2191.

2. Vos, T.; Allen, C.; Arora, M.; Bhutta Z.A.; Brown, A.; Carter, A.; Casey, D.C.; et al. GBD 2015 Disease and Injury Incidence and Prevalence Collaborators. Global, regional, and national incidence, prevalence, and years lived with disability for 310 diseases and injuries, 1990-2015: a systematic analysis for the Global Burden of Disease Study 2015. Lancet. 2016, 388, 1545-1602.

3. Gardiner, S.A.; Laing, N.; Mall, S.; Wonkam, A. Perceptions of parents of children with hearing loss of genetic origin in South Africa. J. Community Genet. 2018, 10, 325-333.

4. WHO Deport, Deafness hearing loss. https://www.who.int/news-room/fact-sheets/detail/deafness-and-hearing-loss. (Archived on 24-Jul-2019).

5. Venkatesh, M.D.; Moorchung, N.; Puri, B.; Genetics of non-syndromic hearing loss. Med. J. Armed Forces India. 2015, 38, 363-368.

6. Snoeckx, R.L.; Huygen, PL.; Feldmann, D.; Marlin, S.; Denoyelle, F.; Waligora, J., et al. GJB2 mutations and degree of hearing loss: a multicenter study. Am. J. Hum. Genet. 2005. 77, 945-957.

7. Estivill, X.; Fortina, P.; Surrey, S.; Rabionet, R.; Melchionda, S.; D'Agruma, S.; Mansfield, E.; Rappaport, E.; Govea, N.; Milà, M.; et al. Connexin-26 mutations in sporadic and inherited sensorineural deafness. Lancet Lond. Engl. 1998, 351, 394-398.

8. Mulwafu, W.; Kuper, H.; Ensink, R.H.J. Prevalence and causes of hearing impairment in Africa. Trop. Med. Int. Health. 2016, 21, 158-165

9. Kelley, P.M.; Harris, D.J.; Comer, B.C.; Askew, J.W.; Fowler, T.; Smith, S.D.; Kimberling, W.D. Novel mutations in the connexin 26 gene (GJB2) that cause autosomal recessive (DFNB1) hearing loss. Am. J. Hum. Genet. 1998, 62, 792-799.

10. Wonkam, A.; Bosch, J.; Noubiap, J.J.N.; Lebeko, K.; Makubalo, N.; Dandara, C. No evidence for clinical utility in investigating the connexin genes GJB2, GJB6 and GJA1 in non-syndromic hearing loss in black Africans. SAMJ South Afr. Med. J. 2015,105, 23-26.

11. Lebeko, K.; Manyisa, N.; Chimusa, E.R.; Mulder, N.; Dandara, C.; Wonkam, A. A Genomic and Protein-Protein Interaction Analyses of Nonsyndromic Hearing Impairment in Cameroon Using Targeted Genomic Enrichment and Massively Parallel Sequencing. Omics J. Integr. Biol. 2017, 21, 90-99.

12. Lebeko, K.; Sloan-Heggen, C.M.; Noubiap, J.J.N.; Dandara, C.; Kolbe, D.L.; Ephraim, S.S.; Booth, K.T.; Azaiez, H.; Santos-Cortez, R.L.P.; Leal, S.M.; Smith, R.J.H.; Wonkam, A. Targeted genomic enrichment and massively parallel sequencing identifies novel nonsyndromic hearing impairment pathogenic variants in Cameroonian families. Clin. Genet. 2016, 90, 288-290.

13. Ingham, N.J.; Pearson, S.A.; Vancolie, V.E.; Rook, V.; Lewis, M.A.; Chen, J.; Buniello, A.; Martelletti, E.; Preite, L.; Lam, C.C.; et al. Mouse screen reveals multiple new genes underlying mouse and human hearing loss. PLOS Biol. 2019, 17, e3000194.

14. Ohlemiller, K.K.; Jones, S.M.; Johnson, K.R. Application of Mouse Models to Research in Hearing and Balance. JARO J. Assoc. Res. Otolaryngol. 2016, 17, 493-523.

15. Nguyen, L.S.; Schneider, T.; Rio, M.; Moutton, S.; Siquier-Pernet, K.; Verny, F.; Boddaert, N.; Desguerre, I.; Munich, A.; Rosa, J.L.; Cormier-Daire, V.; et al. A nonsense variant in HERC1 is associated with intellectual disability, megalencephaly, thick corpus callosum and cerebellar atrophy. Eur. J. Hum. Genet. 2016, 24, 455-458. 
16. Melo, U.S.; Macedo-Souza, L.I.; Figueiredo, T.; Muotri, A.R.; Gleeson, J.G.; Coux, G.; Armas, P.; Calcaterra, N.B.; Kitajima, J.P.; Amorim, S.; et al. Overexpression of KLC2 due to a homozygous deletion in the non-coding region causes SPOAN syndrome. Hum. Mol. Genet. 2015, 24, 6877-6885.

17. Jensen, E. A. H.; Harmon, E. D.; Smith, W. Early identification of idiopathic sudden sensorineural hearing loss. Nurse Pract. 2017, 42, 10.

18. Mark, S. The ear and nose. Textbook of Physical Diagnosis 7th Edition. 2015. https://www.elsevier.com/books/textbook-of-physical-diagnosis/swartz/978-0-323-22148-1. (Archived on 28-Feb-2019).

19. Tewfi, K.; Harpreet, S. Eustachian Tube Function: Overview, Embryology of the Eustachian Tube, Anatomy of the Eustachian Tube. Medscape. 2012, New York, United States of America. (https://emedicine.medscape.com/article/874348-overview) (Archieved on 09 May 2018).

20. Petersen, E.B.; Wöstmann, M.; Obleser, J.; Stenfelt, S.; Lunner, T. Hearing loss impacts neural alpha oscillations under adverse listening conditions. Front. Psychol. 2015, 6.

21. Kindt, K.S.; Sheets, L. Transmission Disrupted: Modeling Auditory Synaptopathy in Zebrafish. Front. Cell Dev. Biol. 2018, 6.

22. Castillo-Davis, C.I.; Mekhedov, S.L.; Hartl, D.L.; Koonin, E.V.; Kondrashov, F.A. Selection for short introns in highly expressed genes. Nat. Genet. 2002, 31, 415.

23. Levy, S.E.; Myers, R.M. Advancements in Next-Generation Sequencing. Annu. Rev. Genomics Hum. Genet. 2016, 17, 95-115.

24. Goodwin, S.; McPherson, J.D.; McCombie, W.R. Coming of age: ten years of next-generation sequencing technologies. Nat. Rev. Genet. 2016, 17, 333-351.

25. Takahashi, S.; Mui, V. J.; Rosenberg, S.K.; Homma, K.; Cheatham, M.A.; Zheng, J. Cadherin 23-C Regulates Microtubule Networks by Modifying CAMSAP3's Function. Sci. Rep. 2016, 6, 28706.

26. Sahly, I.; Dufour, E.; Schietroma, C.; Michel, V.; Bahloul, A.; Perfettini, I.; Pepermans, E.; Estivalet, A.; Carette, D.; Aghaie, A.; et al. Localization of Usher 1 proteins to the photoreceptor calyceal processes, which are absent from mice. J. Cell Biol. 2012, 199, 381-399. 